\title{
Implicit Teaching Strategies on Grammar Instruction: Students' Prevailing Stance
}

\author{
Rizki Indra Guci ${ }^{1}$, Nur Arifah Drajati ${ }^{2}$ \\ Universitas Sebelas Maret ${ }^{1,2}$ \\ rizkiindraguci@student.uns.ac.id ${ }^{1}$
}

\begin{abstract}
Grammar teaching in foreign language education has been maintained by most theories as one thing playing a significant role in facilitating the process of learning to read, write, speak, and understand a foreign language. However, scholars label that role as controversial both in the research of second language acquisition (SLA) and language pedagogy. Thus, such condition results in a potential cause of confusion to teachers and students, then leads the researchers to a thoughtful theoretical debate on the topic of the way grammar should be taught: explicitly or implicitly. The aim of the present case study was to gain an insight into the prevailing stance of Indonesian English students on grammar teaching enrolled in a senior high school. To this end, a questionnaire as well as interview sessions were developed and validated based on one construct pair from SLA literature: explicit versus implicit instruction. The findings, in general, showed that the students were found to prefer implicit over explicit instruction. Nonetheless, the stance somewhat changed depending on the proficiency level of students. As an implication, this study supported Indonesian English students to maintain their stance on implicit teaching strategies on grammar instruction, regarding the help they can get in the process of natural acquisition of language.
\end{abstract}

Keywords: case study, foreign language teaching, grammar instruction, implicit teaching, students' prevailing stance

\section{INTRODUCTION}

Most theories have maintained the study of grammar as one central thing in facilitating the process of learning to read, write, speak, and understand a foreign language as well (Scott, 1989). Scholars supporting the explicit method of grammar instruction are inclined on the importance of explicitly teaching the grammatical structures and rules of the target language in order to organize linguistic elements for communicative purposes. Standing on the other side, those scholars who are inclined to an implicit approach argue that learners of a foreign language will 'naturally' develop the whole grammar competency needed to communicate effectively from exposure to comprehensible and meaningful linguistic input (Scott, 1989). For about two decades, the effectiveness of the implementation of explicit and implicit language teaching 
methods has been a topic of debate. Some scholars, as the proponents of explicit methods of teaching, think that focusing the students' attention on the target learning items in extremely structured environments is of great importance to the L2 learners (Ellis \& Bogart, 2007; Schmitt \& Zimmerman, 2002; Taylor, Marz, Nichos, Rickelman, \& Wood, 2009). There has been a great deal of interest in how implicit and explicit knowledge has been acquired in recent years and what role they play in the performance of second language (L2) learners. Implicit and explicit knowledge has already been obviously described and put into operation (Ellis, 2005; 2009). Thus, the studies are being conducted to test the interventions in form of implicit and explicit (Spada \& Tomita, 2010).

Explicit grammar teaching strategies are believed and designed to further proficiency in all skills. Besides, the students need to pass through a stage of a heavily structured practice of grammatical structures before they can move toward open-ended, creative language (Omaggio, 1984). In addition, to stress this stance on the value of explicit grammar instruction, a controlled processing and automatic processing in learning a foreign language are distinguished, by suggesting that language skills are learned and may become automatic only after the use of controlled processes, thereby supporting the notion that students develop automatic control of a grammatical structure after passing through a deliberate, conscious stage of learning grammatical rules and their application (McLaughlin, 1978).

Thus, another distinction was made between "learning" (a conscious process) and "acquisition" (a subconscious process) that currently forms the basis of a theory of implicit teaching strategies. It was also stated that second language acquisition could be taken place in the classroom without any explicit study of grammar as long as the students are exposed to enough comprehensible input (Krashen, 1985). Likewise, the discrepancy between learning and acquisition was acknowledged in the theory of the Natural Approach (Krashen \& Terrel, 1983). The basic guidelines for this approach include a focus on content over form, immersing students in all the components of the target language from the beginning, error correction on written work only, and allowing for a "prespeaking phase" during the initial stages of the exposure until students feel ready to respond in the target language.

Some researches conducted responding to this controversial issue. Graus and Coppen (2015) studied about student-teacher beliefs on grammar instruction. In their research, the student teacher referred to the undergraduate and postgraduate students of nine universities of applied sciences in the Netherlands. Gheisari and Yousofi (2016) investigated the kind of instruction, implicit exposure or explicit instruction, which was more rewarding for Iranian preuniversity students in Iran on the matter of teaching methods of collocational 
expressions in ESL/EFL contexts. Recently, Loewen and Sato (2018) were also involved in a similar study about this never-ended-like issue. The theory, research, and pedagogy related to the instructed language acquisition and English language teaching were chosen as the focus of their investigation.

However, the author found that there is this lacuna in those studies as mentioned above, the prevailing stance of Indonesian English language teachers and students, and learning outcomes which are simultaneously playing the roles as the impacts, and reasons in some cases, behind the stances mentioned above. Therefore, as the research goal/aim, the researcher hopes that by conducting a case study concerned with several points discussed above, how Indonesian teachers and students portray a grammar teaching and learning process in the classroom -as well how the teaching implementation is- can be clearly explained.

\section{LITERATURE REVIEW}

The role of grammar teaching has been the subject of ongoing discussion for decades in the foreign language classroom. Second language acquisition (SLA) researchers have been discussing how grammar teaching can make a contribution most to language acquisition since about the 1960s. Even though significant progress has been made, the pedagogical relevance of FFI research for teachers is still relatively limited. First, it is not always consistent findings. Second, many unknowns still exist in the current SLA theory. Third, the teacher perspective was primarily ignored by SLA researchers (S. Borg, 1999a; Graus \& Coppen, 2015), and there is still a considerable gap between grammar research and the practice of teachers (Larsen-Freeman, 2015).

The "implicit" and "explicit" labels may apply to many elements of a second language, including knowledge, instruction, and learning. Implicit language knowledge is like a certain thing that can be accessed without any involved consciousness, in time-pressured circumstances, focusing on meaning rather than form, and without using meta-language. Explicit language knowledge is something that the student is aware of, is available only in untimely circumstances, takes a focus on form, and can also be verbalized utilizing metalanguage (Ellis, 2005). Implicit and explicit knowledge is comparable to procedural and declarative knowledge, but not identical (Ellis, 1993). Ellis (2005) revealed that distinct kinds of assignments can be used independently to tap implicit and explicit knowledge: time-pressured, meaning-focused tasks (including oral phrase imitation, oral narrative retelling, and timed grammaticality judgment testing) tap implicit knowledge, and unpressured, form-focused assignments (including untimed grammaticality testing and metalinguistic knowledge testing) tap explicit knowledge. 
The characteristics of implicit and explicit language instruction in the classroom are comparable to those of task design features that tap implicit versus explicit knowledge. Implicit instruction is given spontaneously in another communication-oriented activity, is unobtrusive (minimum interruption of meaning communication happens), introduces target forms in context, makes no use of meta-language, and promotes free use of the target form. On the other side, explicit instruction is predetermined and scheduled as the primary focus and goal of a learning experience, is obtrusive, introduces the target forms in isolation, employs metalinguistic terminology (e.g. explanation of rules) and includes controlled exercise of the target form (Housen \& Pierrard, 2006).

Furthermore, explicit grammar instruction method emphasizes the importance of openly teaching the rules and grammar structures of the target language in order to organize linguistic elements for communicative purposes efficiently and accurately. Explicit grammar teaching strategies are aimed at improving skills in all competencies. While students are encouraged to focus on the target language's content and functions, they need to go through a stage of heavily structured grammatical structure practice before moving towards openended, creative language (Omaggio, 1984). Explicit grammar instruction also emphasizes "skill getting" (teacher-structured manipulation of grammatical elements occurring in fixed, controlled relationships) and "skill using" (use of formally learned structures for personal self-expression) (Rivers, 1981).

McLaughlin, by distinguishing between controlled processing and automatic processing in learning a foreign language, supports the value of explicit grammar instruction (McLaughlin, 1978). He claims that language skills are learned and automatic only after the use of controlled processes, thus promoting the idea that students cultivate automatic control of a grammatical structure after passing through a deliberate, conscious stage of learning and application of grammatical rules. Furthermore, explicit FFI is concerned with 'some rule being thought about during the learning process' (DeKeyser, 1995), which can be deductive and inductive. Explicit teaching leads the focus of learners to the target form, is predefined and designed, and is obtrusive in shifting focus from communication and forming meaning. It is also distinguished by its use of metalinguistic terminology, often involving a component of the target form's controlled practice (Housen \& Pierrard, 2005).

On the contrary, implicit teaching method enthusiasts such as CelceMarcia (2001), Ellis (1997), Gass (1999), Krashen (1994), and Nagy and Herman (1987) claim that there is no need for explicit instruction since adequate exposure to target language input and sequences can result in studying these components. More significantly, there is a group of moderate implicit exposure supporters challenging Krashen's substantial claim (1981) to mere exposure as the main 
factor in language development. Such experts believe that some exposure on its own is essential but not sufficient to learn the features of the target language included in any particular type of input. According to such academics, the skillful implementation of certain methods of input enhancement, such as input flooding and text improvement, can play a significant role in drawing the attention of learners to the target items and thereby improving the learning process (Schmidt, 1990; Smith, 1993).

Moreover, scholars who favor an implicit approach argue that all the grammar skills they need to communicate effectively from exposure to comprehensible, meaningful linguistic input will be developed "naturally." The differentiation between "learning" (a conscious process) and "acquisition" (a subconscious process) made by Krashen forms the foundation of his theory of implicit teaching strategies (Krashen, 1983). He maintains that the acquisition of the second language can take place in the classroom without any explicit grammar study if the students are exposed to sufficient understandable input. Indeed, he suggests that conscious grammar study does not help in the process of natural acquisition: “... grammar exercises ... can be valuable as tools to encourage learning. However, it should be kept in mind that while their function is important, very little acquisition will take place during their use" (Krashen \& Terrell, 1983).

Likewise, in his theory of the Natural Approach, Terrell accepts the distinction between learning and acquisition. The basic guidelines for this approach include focusing on content over form, immersing students in all the target language components from the beginning, correcting errors only on written work, and making a "pre-speaking phase" possible during the initial exposure stages until students feel ready to respond in the target language (Krashen \& Terrell, 1983).

In addition, implicit instruction involves 'learning that takes place without either intentionality or awareness' (R. Ellis, 2008). Implicit teaching is based on exposure (input) and communication with more advanced speakers, a paradigm based on the acquisition of the first language. An exemplar-based model is an example of implicit teaching; it is essentially a connectionist and probabilistic paradigm which claims that learners take grammatical structures from encountering (semi-)formulaic morpho-syntactic structures (N. Ellis, 2002).

Two significant meta-analyzes of adult L2 learner short-term research (Norris \& Ortega, 2001; Spada \& Tomita, 2010) indicate that explicit treatments tend to cause considerably bigger sizes of effects than implicit treatments. Explicit treatments (coded as such if "rule explanation included an aspect of the instruction" or "if learners were immediately requested to engage specific types and attempt to generalize meta-linguistics on their own") include an explanation 
of the grammar rule, comparisons between the first language (L1) and L2, and metalinguistic feedback. Implicit treatments (in which "neither rule presentation nor directions to attend to particular forms were part of a treatment") included input floods, interactions, and recasts (Norris \& Ortega, 2001). Occasionally, researches have shown that implicitly instructed adults can be equivalent to explicitly instructed adults (e.g., Morgan-Short, 2007), but this research body is still tiny if it is compared to the lengthy history of explicit instruction studies.

Other than the two parties mentioned above, some other researchers say that the combination of both implicit and explicit language teaching methods can have a facilitative impact on the development of learners (Hunt \& Beglar, 2005; Öztina, 2009).

\section{METHODOLOGY}

This research was a case study undertaken using a qualitative method to discover the relevant information on how high school Indonesian EFL learners identified the significance of grammar and conceptualized their connection with their language skills, as well as the ideal teaching strategies they adhered to on grammar instruction. The basic reason for using a qualitative method was that this research worked on undertaking a thorough inquiry into the anticipated information and trying to figure out the particularities as well as the uniqueness of the information rather than simply reporting the limited perspectives of the information. The following details illustrate this study's participants, instrument, procedure, data analysis, and the trustworthiness of this study.

\section{Participants}

This research involved 45 Indonesian EFL high school learners learning English as one of the subjects at one of senior high schools in Bengkulu, Indonesia. Thirty-one of them were female, while others were male. They ranged from the age of 17 to 18 . They were considered relevant and appropriate to be the participants of this study since they were learning English on a certain level needed by the researcher in conducting this study. Furthermore, they were taught grammar - which was the main discussion of this study- by their English teachers. Those students were recruited on the basis of purposive sampling with the following criteria: First, they were sufficiently knowledgeable regarding their level of English proficiency. Second, they were adequately experienced in the matter of Grammar teaching and learning process. Third, in turn, they were personally willing to be included in this research. 


\section{Instruments}

The whole data of this study were collected from an open-ended questionnaire and interview sessions assigning six questions. The first question dealt with data relevant to the grammar importance recognized by this study's respondents. The second question was distributed to examine the data about the connection between grammar skills of learners and English language proficiency. The third question was about the significant English learning priority of the learners. The fourth aimed at finding the most significant skill among English's major skills (Listening, Speaking, Reading, Writing, Grammar, and Vocabulary). The remainder of the questions were subsequently allocated to investigate the prevailing position of the learners on the ideal teaching strategies on grammar instruction.

\section{Procedure}

The processes of questionnaire distributions were carried out from the 2nd of June 2019 up to the 4 th of June 2019. Then, the interview sessions were conducted from the 7th of June 2019 up to the 23rd of June 2019. Depending on their spare moment, the participants were provided the option of the proper time to distribute the questionnaires and hold the interview sessions so that each participant could share the expected clear information with few external impediments. The questionnaires and interview sessions were completed using the Indonesian language in order to make it easier for the learners (participants) to provide the accurate and fundamental information regarding the targeted information. To ease the distribution process and save the time spent, the questionnaires were distributed using one of the chat-room applications. The interview sessions were recorded to assist the researcher in initiating further information transcription. Subsequently, the transcripts were translated into proper English. The interview sessions were conducted several times to achieve the trustworthiness of the data.

\section{Data Analysis}

To analyze the data acquired, this research used the interactive data analysis model of Miles \& Huberman (1984) whose method consisted of data collection, data reduction, data display and conclusion drawing.

The researcher used an open-ended questionnaire and interview sessions as techniques for revealing and collecting data in the form of information regarding the student's prevailing position on the importance of grammar, the link between learners ' grammar skills and English language proficiency, the learners' important English learning priority, the most important skill among the major skills of English, as well as the prevailing stance of learners on the ideal teaching strategies on grammar instruction. All the collected data were systematically 
grouped for data reduction processes based on the coded topics identified as representing any needed information relevant to each issue of this research. With regard to data display, the theme-based information correctly grouped were subsequently displayed in the questionnaire data as well as the subsequent interview transcripts. In addition, this study's results have been critically discussed. Furthermore, the findings of this study were critically discussed. In turn, a brief and representative overview relevant to the displayed and discussed information was written at the end as connected to the conclusion drawing. The researcher also studied the trustworthiness of information before setting out the results of this researchby re-interviewing some learners to obtain some of the necessary details of the information. The procedures were performed in the same manner as the four steps above. Other needed strategies were also implemented to achieve the ideal trustworthiness.

\section{FINDINGS AND DISCUSSIONS}

This section provides the findings which orientate the data towards the following issues: 1) the importance of grammar learning, 2) the relation between students' grammar proficiency and students' English proficiency, 3) the ideal grammar learning in students' perception. The findings are displayed through descriptions and several representative questionnaire transcripts that follow. The selected transcripts have been appropriately discerned and considered representative towards other students' views, which possess the same notions.

\section{The importance of grammar learning}

Based on the questionnaires distributed, there were 41 out of 45 students argued that grammar is essential/essential, and standing as the opposite; the other four students stated that grammar is unimportant. From the overall answers given by the students, there were four varieties of points of view. The following transcripts are appropriately chosen to depict those varieties.

\footnotetext{
Question: What do you think about the importance of grammar learning?

Student 12: Very important. Because in English, grammar is very influential in the communication process. Even a little mistake/error in grammar may cause different meanings.

Student 3: Quite important, because understanding Grammar is needed at this time. For example, when you want to enter college or to get a certain scholarship, you are required to get a high TOEFL score.

Student 9: In my opinion, grammar is an important thing and an element that must be learned. Grammar teaching is important because it can make it easier for someone to understand and master English.

Student 19: Not so important because grammar is not a requirement to be able to communicate using English.
} 
Student 27: My target is to prioritize my English skills above grammar learning because English language skills are more critical while grammar can catch up afterward.

Based on the above transcripts, student 12 provided a relation between grammar and the communication process in her answer; she stated that a little mistake/error made in grammar might even produce different meanings delivered in communication so that grammar becomes one vital stuff to learn in English to avoid such thing. Student 3 thought that grammar is quite essential in relation to the university and scholarship admission test. In her argument, she implies that grammar plays a specific role in reaching the next level of education possessed by the students. So, that is why grammar is needed this time. Student 9 stated that grammar is an important thing to be mastered since it has something to do with someone's English proficiency. So, in order to make the learning process easier, learning grammar is worth doing. Besides, for her, the better the grammar skill owned by a student, the better English proficiency he/she masters. In turn, student 19 had a different answer. In her answer, he stated that grammar is not so crucial since grammar is not a prerequisite of being able to communicate in English. Afterward, student 27 came up with her argument, which was putting grammar skills below other English significant skills in the scale of priority. She thought that learning grammar could come after focusing on the mastering of other English skills, and this is somehow implicitly in line with the theory proposed by Krashen (1983), all the grammar skills the students need to communicate effectively from exposure to comprehensible, meaningful linguistic input will be developed "naturally."

\section{The relation between students' grammar proficiency and students' English proficiency}

The students revealed varied answers in the form of a relation between students' grammar proficiency and students' English proficiency. Eventually, 41 students agreed that there is a relation between students' grammar proficiency and students' English proficiency. However, the rests, four students argued that those two do not have any relation. The variations of answers and reasons followed are represented by transcripts below.

\footnotetext{
Question: What do you think about the relation between students' grammar proficiency and students' English proficiency?

Student 32: Strongly related, because grammar is one of the most difficult skills in English; therefore, the higher a person's understanding of grammar, the better his English skills are.
} 
Student 1: I think an understanding of grammar helps improve one's English skills, and those two are related. Understanding of grammar can help us to understand a sentence or conversation in English well.

Student 3: $\quad$ Those two are not related, because someone's language skills are not only seen from his grammar skills.

Student 18: To my knowledge, grammar skills are used as a complement in English because communication skills take precedence over grammar skills.

In accordance with the above transcripts, student 32 stated that grammar certainly determines someone's English proficiency level regarding its difficulty level. She explained that the higher someone's grammar proficiency means the better English skills mastered. Also, student 1 agreed upon the same thing but provided a different reason. In her opinion, grammar proficiency may lead someone to be able to understand the conversation done in English well. By reading these two arguments discussed as the representations of the other with similar points, the researcher could conclude that they are exactly like what Scott (1989) claimed, grammar facilitates the process of learning to read, write, speak, and understand a foreign language as well. After all, student 3 gave a different argument. Responding to the question, she declared that there is no relation between students' grammar proficiency and students' English proficiency. The reason is, in her point of view, the language skills possessed by someone may not be determined by merely looking at his/her grammar skills. By this, she implicitly stated that they are still other things about English which are worth focusing on.

Furthermore, student 18 came up with his argument as a supporter of the later stance. He agreed that grammar only plays the role of a complement in a matter of English skills proficiency. To this end, he put communication skills above grammar.

\section{The ideal grammar teaching and learning process in students' perception}

Based on the answers given by the participants in the questionnaires distributed, there were 31 out of 45 students preferred explicit learning of grammar. The following transcripts are representative of those answers.

\footnotetext{
Question: How is the ideal grammar teaching and learning process in your opinion?

Student 1: $\quad$ By studying the materials or rules in grammar according to the grammatical points, and then proceed by doing some exercises continually so that the understanding may be better.

Student 11: I think, maybe, by the details of the material accompanied by an example and then followed by exercises.

Student 14: By learning and understanding the basic concepts of grammar in the first place and immediately practicing it. There are also many ways to learn grammar, either by searching for material on the internet (self-taught learning) or by taking English courses.
} 
According to the transcripts above, the researcher interpreted that 31 participants are in line with the theory about explicit FFI which is concerned with 'some rule being thought about during the learning process' (DeKeyser, 1995). Student 1 stated that an ideal grammar learning means getting some focus attached to the grammatical points in the first place, and after that, the exercises coming continually may be used as the enrichment to the knowledge mastered. Student 11 agreed upon the same thing by adding the term of the material details that should exist in a grammar learning process. And, of course, followed by a number of exercises afterward. Besides, student 14 added something beyond those basic concepts and practices of grammar. She stated that learning grammar could also be done by the help of the internet, and the students can access and learn the materials needed by themselves. Alternatively, as another option, English courses may be considered as another hand in this matter. Apparently, the answers given by those students above lead them to be classified as the parties who tend to learn grammar explicitly, considering the fact that scholars who support an explicit grammar instruction method emphasize the importance of openly teaching the rules and grammar structures of the target language in order to organize linguistic elements for communicative purposes efficiently and accurately (Omaggio, 1984).

Meanwhile, other 14 students declared their preferences in learning grammar implicitly than learning grammar explicitly. Their answers were represented by several transcripts follow.

Student 4: We can read some writings written in excellent and correct Grammar. Because, by that, we can also automatically write and speak in correct grammar.

Student 6: $\quad$ We can start with simple things like English song lyrics and games.

Student 18: In my opinion, a good grammar learning must begin with the understanding of students in English-language communication. Then, grammar is added as the perfection to the lacks found in communication skills when the students are getting used to English.

In relation to the above transcripts, the researcher interpreted that 14 participants could be classified into the supporters of implicit learning of grammar regarding the explanations they provided in their answers. Krashen maintains that the acquisition of the second language can take place in the classroom without any explicit grammar study if the students are exposed to sufficient understandable input (Krashen, 1983). Focusing on the transcripts, student 4 stated that learning grammar could be done by doing some readings because it can make her write and speak by using correct grammar automatically. By saying 'automatically' means that she agreed to the argument saying that learning grammar does not have to come up with the intentionally set up the learning process. Student 6 said that he could even begin to learn grammar by using the lyrics of English songs and also 
games instead of merely focusing on studying grammar itself. In other words, he may support this term of the fun English way of learning. Also, student 18 preferred a grammar learning process, which is combined with the study of speaking. By this, he thought that the students can begin with the understanding of English-communication skills in the first place instead of directly explicitly focusing on learning grammar. However, the grammar may still be involved in the process, but not more than a perfection towards the lacks found in mastering the skills of communication. After all, the researcher concluded that these representing arguments by the three students are precisely in line with the theory proposed by R. Ellis, implicit instruction involves 'learning that takes place without either intentionality or awareness' (R. Ellis, 2008).

\section{CONCLUSION}

In accordance with this study findings and discussions, the importance of grammar in a language teaching and learning process based on the students' perception were eventually varied and followed by several reasons, they were related to the important role grammar plays in a communication process, the needs for a certain selection of job vacancy and university admission test, and also the indicator of someone's English proficiency level. However, a few students were thinking that grammar is not that important for English teaching and learning process since grammar is not identified as a certain prerequisite of being able to take part in a communication in English. Afterward, the participants gave the other varied response to the question about the relation between students' grammar proficiency and students' English proficiency level. Some students agreed that there was a relation between grammar proficiency and English proficiency level, they stated that the higher someone's grammar proficiency, the better English skills he possesses. Then, some stated that being in a right proficiency level of grammar may lead them into a better level of understanding towards the conversations done in English. However, there was this different answer saying that grammar proficiency level possessed by someone has nothing to do with his English proficiency level since it may not be determined by merely focusing on grammar proficiency.

Furthermore, in relation to the ideal grammar teaching and learning process, the participants are inclined into the explicit teaching and learning of grammar instead of the implicit. This was regarding 31 out of 45 students agreed that learning grammar explicitly is more effective for them than doing it explicitly. However, 14 students argued that learning grammar implicitly, or studying it without paying a total focus on it is valid and classified into an ideal teaching and learning process of grammar. This result of the research was 
considered in line with the predecessors. First, the research studied about studentteacher beliefs on grammar instruction by Graus and Coppen (2015), which was ended by the fact that the participants tend to support the explicit teaching and learning of grammar. However, the difference is, the research by Graus and Coppen was using the student teacher in a university level as the respondents. Another research was done by Gheisari and Yousofi (2016), with the investigation on the kind of instruction, implicit exposure, or explicit instruction, which was more rewarding for Iranian pre-university students. The results of the study also showed that the Iranian pre-university students were inclined into the explicit instruction, although there were several participants saying that they were more into the implicit exposure to be the ideal way of teaching and learning grammar for them. 


\section{REFERENCES}

Borg, S. (1999a). Studying teacher cognition in second language grammar teaching. System, 27, 19-31.

Brown, R. (1979). REFERENCE Brown, R. (1973). A first language: The early stages. Cambridge, Mass.: Harvard University Press. 135-137.

Celce-Marcia, M. (2001). Teaching English as a second or foreign language. Boston, MA: Heinel \& Heinel.

Degirmenci, N., \& Yavuz, F. (2015). Pre-service Teachers' Attitudes Towards Grammar Teaching, 191, 1828-1832. https://doi.org/10.1016/j.sbspro.2015.04.353

DeKeyser, R. (1995). Learning second language grammar rules: An experiment with a miniature linguistic system. Studies in Second Language Acquisition, 17, 379-410.

Ellis, N. (2002). Frequency effects in language processing: A review with implications for theories of implicit and explicit language acquisition. Studies in Second Language Acquisition, 24, 297-339.

Ellis, N. C., \& Bogart, P. (2007, October 1-3). Speech in language technology in education: The perspective from SLA research and practice. In Proceedings of Sla TE workshop on Speech and Language Technology in Education ISCA Tutorial and Research Workshop, Famington, PA.

Ellis, R. (2006). The structural syllabus and second language acquisition. TESOL Quarterly, 27(1), 91. https://doi.org/10.2307/3586953

Ellis, R. (1997). SLA research and language teaching. Oxford: Oxford University Press.

Ellis, R. (2008). The study of second language acquisition. 2nd edition. Oxford: Oxford University Press.

Ellis, R., \& Roever, C. (2018). The measurement of implicit and explicit knowledge. The Language Learning Journal, 0(0), 1-16. https://doi.org/10.1080/09571736.2018.1504229

Ellis, Rod. (2005). Measuring implicit and explicit knowledge of a second language: A psychometric study. SSLA 27. 141-172.

Ellis, Rod. (2009). Implicit and explicit learning, knowledge, and instruction. In Rod Ellis, Shawn Loewen, Catherine Elder, Rosemary Erlam, Jenefer Philp, \& Hayo Reinders (eds.), Implicit and explicit knowledge in second language learning, testing, and teaching, 3-26. Buffalo, NY: Multilingual Matters.

Fujino, H. (2019). L2 learners' perceptions of grammar: the case of JFL learners in the UK. Language Learning Journal, $0(0), 1-15$. https://doi.org/10.1080/09571736.2019.1578399

Gass, S. (2012). Incidental Vocabulary Learning. Encyclopedia of the Sciences of Learning, 1519-1519. https://doi.org/10.1007/978-1-4419-1428-6_2213

Gheisari, N., \& Yousofi, N. (2016). Iranian pre-university student's retention of collocations: Implicit exposure or explicit instruction. Cogent Education, 3(1), 1-12. https://doi.org/10.1080/2331186X.2016.1184826 
Graus, J., \& Coppen, P. (2015). Defining grammatical difficulty: a student teacher perspective. $\quad$ Language Awareness, 37-41. https://doi.org/10.1080/09658416.2014.994639

Graus, J., \& Coppen, P.-A. (2016). Student teacher beliefs on grammar instruction. Language Teaching Research, 20(5), 571-599. https://doi.org/10.1177/1362168815603237

Housen, A., \& Pierrard, M. (2005). Investigating instructed second language acquisition. In: A. Housen, \& M. Pierrard (Eds.), Investigations in instructed second language acquisition (pp. 1-30). Berlin: Mouton de Gruyter.

Hunt, A., \& Beglar, D. (2005). A framework for developing EFL reading vocabulary. Reading in a Foreign Language, 17, 23-59.

Krashen, Stephen. (n.d.). Principles and practice in second language acquisition.

Krashen, S. D. (1981). Second language acquisition and second language learning. Oxford: Pergamon Press.

Krashen, Stephen. (1985). The Input Hypothesis. New York: Longman.

Krashen, Stephen \& Tracy Terrell. (1983). The Natural Approach. Hayward, CA: Alemany.

Krashen, S. D. (1994). The input hypothesis and its rivals. In N. C. Ellis (Ed.), Implicit and explicit learning of languages (pp. 45-78). San Diego, CA: Academic Press.

Larsen-freeman, D. (2015). Research into practice: Grammar learning and teaching. (March), 263-280. https://doi.org/10.1017/S0261444814000408

Lichtman, K. (2013). Developmental Comparisons of Implicit and Explicit Language Learning. (October 2014), 37-41. https://doi.org/10.1080/10489223.2013.766740

McLaughlin, Barry. (1978). "The Monitor Model: Some Methodological Considerations. ” Language Learning 28: 309-32.

Morgan-Short, Kara. (2007). A neurolinguistic investigation of late-learned second language knowledge: the effects of implicit and explicit conditions. Washington, DC: Georgetown University dissertation.

Nagy, W. E., \& Herman, P. A. (1987). Breadth and depth of vocabulary knowledge: Implications for acquisition and instruction. In M. G. McKeown \& M. E. Curtis (Eds.), The nature of vocabulary acquisition (pp. 19-35). Hillsdale, NJ: Lawrence Erlbaum.

Norris, John \& Lourdes Ortega. (2001). Does type of instruction make a difference? Substantive findings from a metaanalytic review. Language Learning, 51. 157-213.

Omaggio, Alice. (1984). Teaching for Proficiency, the Organizing Principle. Lincolnwood, IL: National Textbook.

Öztina, S. (2009). Effects of input flood and negative evidence on learning of make/do collocations: A study with seventh grade Turkish EFL students (A dissertation submitted to the graduate school and research in the fulfillment of the requirements for the degree master of arts). Anadolu University Institute of Educational Sciences, Eskişehir. 
Rivers, Wilga. (1981). Teaching Foreign Language Skills. Chicago: Univ. of Chicago Press.

Loewen, S., \& Sato, M. (2018). Instructed Second Language Acquisition and English Language Teaching: Theory, Research, and Pedagogy. Switzerland: Springer Nature Switzerland.

Schmidt, R. (1990). The role of consciousness in second language learning. Applied Linguistics, 11 , 129-158. http://dx.doi.org/10.1093/applin/11.2.129

Schmitt, N., \& Zimmerman, C. B. (2002). Derivative word forms: What do learners know? TESOL Quarterly, 36, 145-171. http://dx.doi.org/10.2307/3588328

Scott, V. M. (1989). An Empirical Study of Explicit Vs. Implicit Teaching Strategies in Foreign Language Instruction. ProQuest Dissertations and Theses, 73(1), 110

Smith, M. (1993). Input enhancement in instructed SLA. Studies in Second Language Acquisition, 15, 165-179. http://dx.doi.org/10.1017/S0272263100011943

Spada, N., \& Tomita, Y. (2010). Interactions between Type of Instruction and Type of Language Feature: A Meta-Analysis. Language Learning, 60(2), 263-308. https://doi.org/10.1111/j.1467-9922.2010.00562.x

Tammenga-Helmantel, M., Arends, E., \& Canrinus, E. T. (2014). The effectiveness of deductive, inductive, implicit and incidental grammatical instruction in second language classrooms. System, 45(1), 198-210. https://doi.org/10.1016/j.system.2014.06.003

Taylor, D. B., Mraz, M., Nichols, W. D., Rickelman, R. J., \& Wood, K. D. (2009). Using explicit instruction to promote vocabulary learning for struggling readers. Reading and Writing Quarterly, 25(2-3), 205-220. https://doi.org/10.1080/10573560802683663 